\title{
The Effects of Waste Recycling on The Employees and The Environment
}

\author{
Mohammad O. Alnais \\ College of Technology at Hail, Hail, Saudi Arabia
}

\begin{abstract}
:
The subject of "waste" has become a very important topic and is really a big problem, which could seriously threaten the health of all humans, especially from such waste that contains nuclear radiation and chemicals. Therefore this matter has become an important topic worldwide.

Hail composi plant(200 tons/day capacity) has been chosen for the area of research as an example to assist a questionnaire, which contains several queries related to the health and safety facing it's employees. After collection and analysis of the questionnaire, it indicated that there are serious health problems related to the skin, eyes, chest, ears etc.

Further, the answers of most of the employees show a very high interest in being involved in the other kinds of council jobs. Therefore a change either weekly or monthly is needed for the employee.
\end{abstract}

\section{Introduction:}

Recently the investigations and research in health and environment has given great importance to the waste recycling programs in the Kingdom of Saudi Arabia, EGC countries and worldwide. The most recent studies such as Mohamed Al-Kateb [1], Amen Al- Nowawe [2], Abu Ghazara [3] and other indicate that the waste recyclable in the Kingdom of Saudi Arabia and EGC countries is only around $5 \%$ from the total waste collected and the remaining waste is either burnt or buried. This it seems is not equivalent to the development standards that these countries have reached. The method, which is used to dispose of the remaining waste, is hazardous to both humans and the environment due to the gases released.

Investigations worldwide have given the environment great attention especially towards the methods of waste recycling. For example in the United States of America many methods have been created over the last few decades to assist in

\footnotetext{
Manuscript received from Dr. Mohammad Othman Alnais

Accepted on : 18/3/2001

Engineering Research Journal Vol 24,No 2, 2001 Minufiya University, Faculty Of

Engineering, Shebien El-Kom, Egypt, ISSN 1110-1180
} 
developing more efficient waste management programs, such as Macdonald [4] who focuses on models whose computational structures have been published of formally presented. By providing this information an understanding of future modeling needs become apparent.

Graziano and Daniels [5] have developed new approaches to waste oil reduction and reuse. This study was conducted to identify and assess opportunities for increasing the recovery and recycle of waste oils. This emphasis of the study was on establishing a consistent methodology that can be used to prioritize reduction, reuse and recycling.

From a practical point of view Bryant and Tolson [6] have exercised an experiment in Newark, USA. The experiment involves a population of approximately 300,000 people and an estimated 110,000 households. The residents are required to separate bottles, cans and newspapers for biweekly curbside collection rotates so that newspapers, glass bottles and cans are collected every other week. The experiment has been successful and there are future possibilities for this type of experiment being taken place in other towns and cities. Such an experiment is both environmentally and cost effective as well as the fact that the waste is sorted out straight after use it does not mingle with non-recycling waste.

Another example of such an experiment has taken place in more than half the homes within a section of San Francisco [7]. It is the cities first major curbside recycling program, a success by any standards. Other than determining what is recyclable and what must go into non-recyclable waste, the only separation of materials required is that residents bag paper products separately. All other recyclable items are placed into a single plastic bin.

Scientists today are finding new methods to recycle just about every type of product released into our environment, if it is unrecycable then they finding a much more safe and easier way to dispose of it. That even includes the recycling of human and animal excreta. An experiment of this sort is taking place in Japan undertaken by Closed Ecology Experiment Facility in 1992 [8]. This experiment is designed for the waste collection and transfer system. Mineral rich wastes such as urine and wool grease must be separated from other wastes to recover the minerals. Solids and liquids also require separate handling methods. The Japanese design uses inclined conveyer belts to separate feces and urine. A flouro-carbon polymer coating prevents wastes from sticking to the belt. In-line freezers are used to solidify liquid wastes and related premature decomposition.

Such experiments are essential for designing the self-contained environment. Another method of recycling human excreta is taking place in the UK. It proves to be a more cost effective method of recycling human and animal excreta and one that might add has been used in the animal sense to enrich and fertilize land for many years in Europe. Journal of the chartered institution of water and environment, 1996, [9] have thought of another useful, which involves recycling, the sludge (excreta) to agricultural land and incineration (with energy recovery) will be the major disposal options for sludge in the future. 
Environmental pressures on sludge recycling to land may lead to restrictions on applications in terms of nitrogen content and more stringent limits for metals in solids. Attention to sludge quality and the development of quality management practices in utilization or disposal operations will help to minimize environmental concerns.

The investigations, which relate on its employees, are scarce. These employees seem to be a forgotten part of the recycling system although they are one if not the most important factor of the system because it is they who come directly into contact with the dangers associated with recycling waste.

All other fields of factory work have acknowledged the fact that their employees come into direct contact with problems related to their individual type of work, which in turn have effect on their health, life style and quality of life in general. For example Morgan W.K.C., Reger 1997 [7] illuminated how the employees" health was affected by diesel emissions, which was released by the machinery in the workplace. Some of the effects included eye irritation, dry itchy throat and a severe cough, which continued even when the employee left that place of work.

\section{Plant Deseription- Compost Plant}

The plant is designed to treat 100 tones per day of domestic refuse, over a single shift operation. As a whole, the plant consists of three sections; (a) the physical treatment plant (b) the biological Treatment plant (c) the final treatment plant. Below is a brief description of each plant.

\section{(a) Physical treatment plant}

The refuse is received in clients' collection vehicles and is deposited in the reception hall of the plant, Fig (1). Clients front end loading shovel will then transfer the refuse into the reception hopper, feeding the plant. The rate of feed is controlled by a single stage "horizontal / inclined" plate feeder, which is proved with a variable speed drive. At the change between the horizontal and inclined sections, the "balling" effect of a moderate feed of refuse, will tend to level out the material bed prior to the refuse passing into the pulverizes.

Items, which should not be fed into the system, are detailed on the list of "Items unsuitable for pulverization", which will be found under the pulverization section. The pulverize is capable of handling a throughout of 15 tones per hour, with surges up to 20 tones per hour of refuse, having an average bulk density of $260 \mathrm{~kg} / \mathrm{m}^{3}$. Certain items, which are unpulverizable, are automatically rejected from the pulverizer, and are deposited into a skip. The pulverized refuse is discharged onto an inclined toughed belt conveyor, which transfers the material to the primary screen.

The Screen is of the single stepped deck resonance long stroke, LAMRICH type, with a screen mesh size of $40 \mathrm{~mm}$. The oversize from the screen (rejects) will be discharged onto the rejects transfer conveyor where it is conveyed to clients rejects baler. The fines collecting conveyor will collect the minus $40 \mathrm{~mm}$ product from the screen. It is then fed into the two stage mixing screws 
where the refuse is mixed with water to increase the moisture content to $55 \%$. From the mixing An over band magnetic separator is located over the head pulley of the inclined conveyor, which extracts ferrous materials and diverts them onto the metals transfer conveyor. The metals transfer conveyor transfers the collected metals to client's metals baler. This conveyor has the facility to be reversed, so as metals may be fed to an upper-top container, if required, as a bypass facility. The magnetically separated refuse from the inclined conveyor is fed to the primary screen.

Screws, the material is fed onto the compost feed conveyor, which transports it to the compost building, and onto a reversing shuffle conveyor

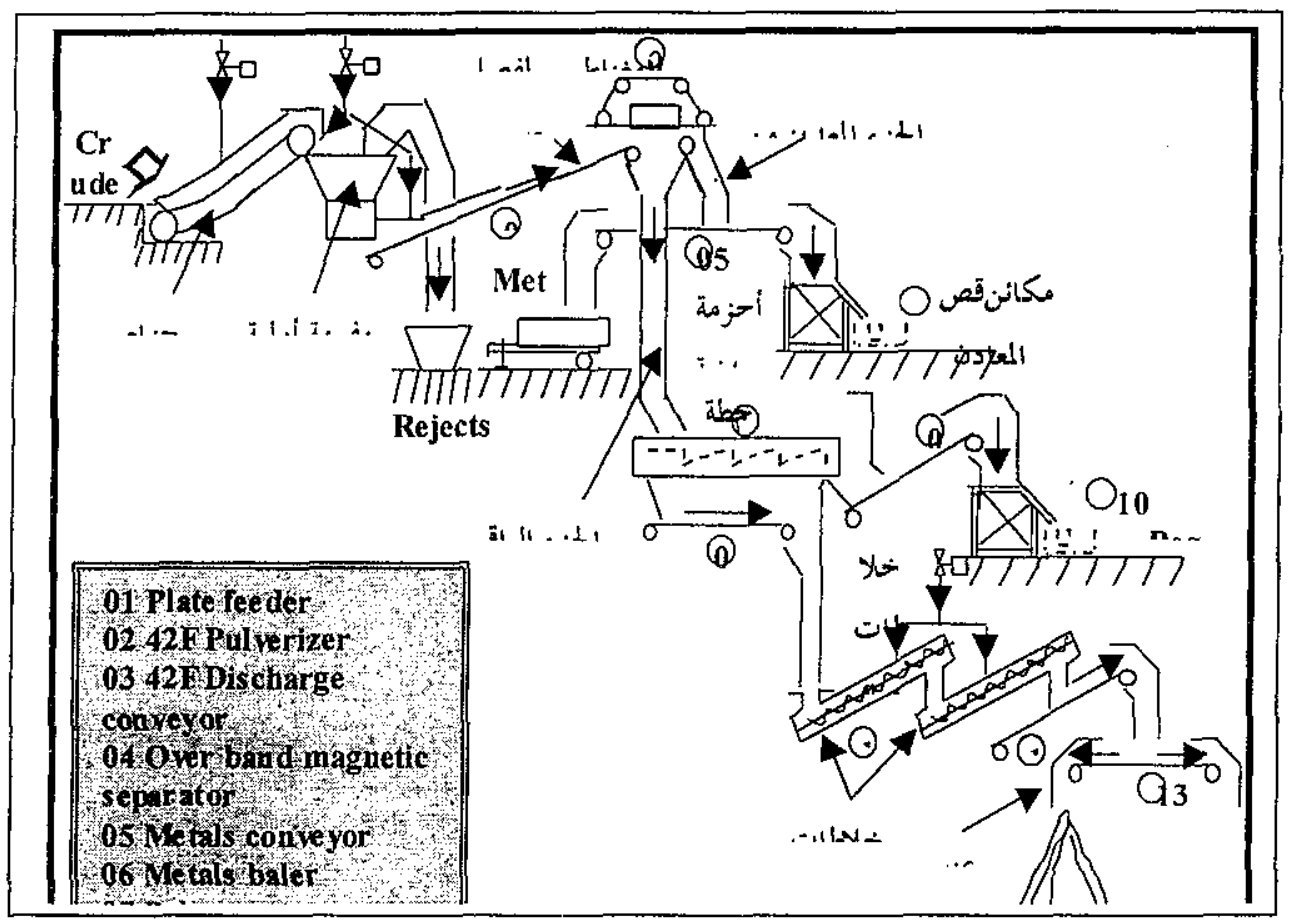

Fig(1) flow diagram for physical treatment plant

\section{(b) Biological Treatment plant}

In this part of the plant the compost process takes place. This process is an accelerated aerobic fermentation method. After fermentation the product is transported to the maturation building by conveyor and stocked out in heaps for the maturation time period. Conveyor to the final treatment then transports the product

\section{(c) Final Treatment plant:}

The matured compost from the maturation area will be transferred into the reception hopper on the metering belt feeder (Fig 2) by means of client front end loading shovel. The rate of the feed is controlled by a restructure plate at the exit from the hopper, which will level out the material bed depth, prior to the material passing on to the transfer conveyor, which in turn feeds onto the fines 
grinder feed conveyor. At the head of this conveyor there is a glass separator. This consists of fan unit and nozzle, which blows high-pressure air across the trajectory of the material from the fines grinder, feed conveyor.

The belt speed of this conveyor is chosen such that glass and other heavy particles are thrown through the air stream and into client's collection skip. However lighter particles are blown out of the trajectory and into the fines grinder where the material is ground to $90 \%$.

The fines grinder discharges onto the screen feed conveyor, which conveys the compost to the final screen. The screen is of the single stepped deck is of the single stepped desk resonance long stroke, FLAMIUCH type, with a screen mesh size of $15 \mathrm{~mm}$. The oversize from the screen (rejects) will be discharged via a chute directly into clients out loading containers. The minus $15 \mathrm{~mm}$ product from the screen will be collected by the fines collecting conveyor. It is then conveyed along two more conveyers until it reaches the bagging plant feed conveyor where it is bagged and stacked onto pallets suitable for handling by forklift trucks.

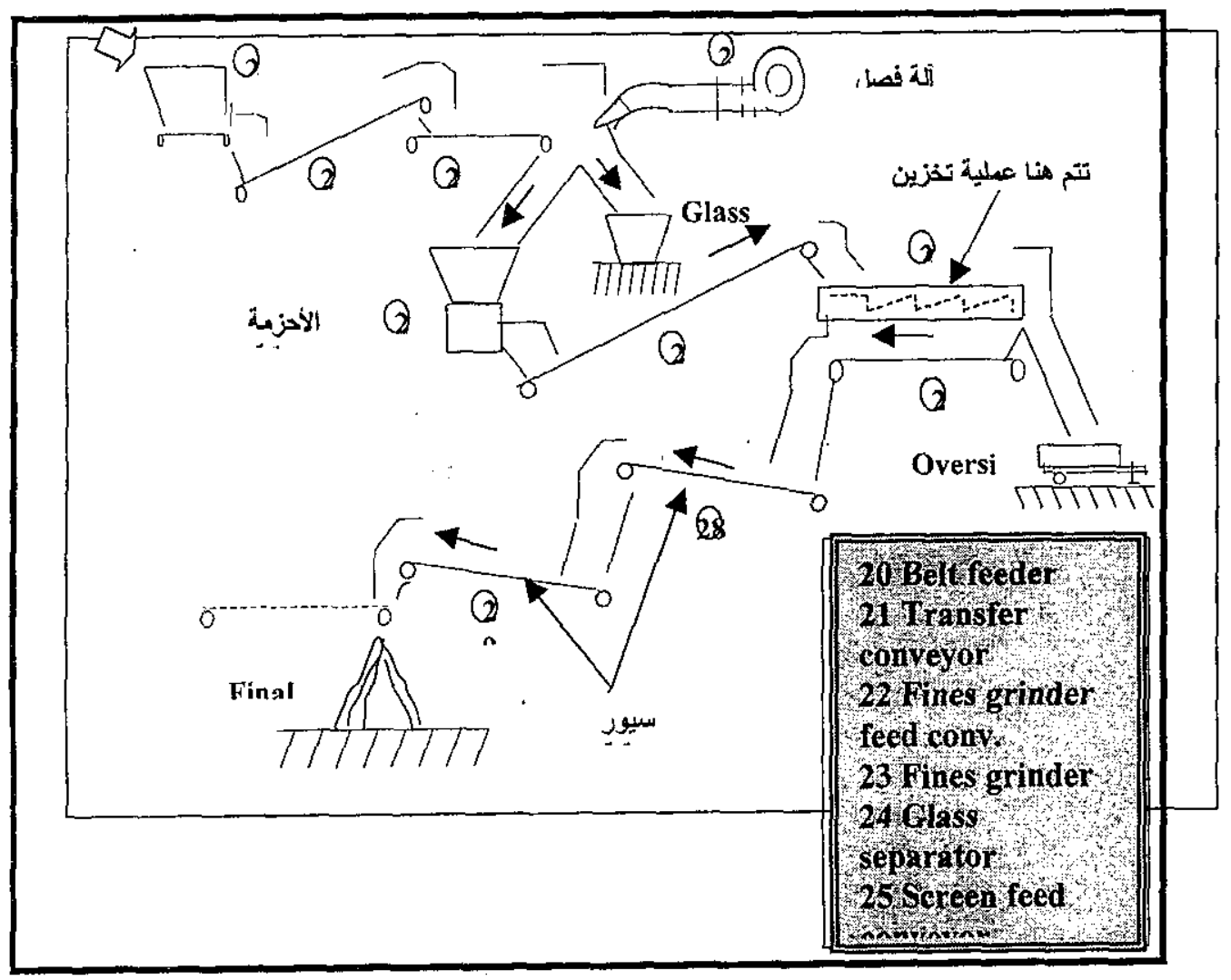

Fig. (2) flow diagram for final treatment plant

\section{Analytical Results}

This section deals with the results obtained from the employees in the field of waste recycling, at Hail composting factory. After several meeting and consultations with the engineer in charge, a questionnaire contains several 
questions about the employees work, safety and health conditions has been prepared, Appendix (I). This questionnaire has been designed to avoid any personal questions, which could cause embarrassment, which could therefore affect the employees' answer.

Lately, many investigations have dealt with employee's job satisfaction. This has been shown clearly in the work conditions such as a waste-recycling factory, which was confirmed by the answers obtained from the questionnaire. The answers show that most of the employees show a very high interest in being involved in the other kinds of council jobs. Therefore a change either weekly or monthly is needed for the employee either in the same factory or in some other part of the council. This agrees with the present research results, which shows that about $80 \%$ of the workers indicate an interest to move or change job in a different department of the council.

Regarding the Industries Safety, the present investigation shows that most of the safety equipment such as shoes, masks, glasses, goggles and gloves are all available upon request. The employees who do use the safety equipment are only $70 \%$, Fig (3).

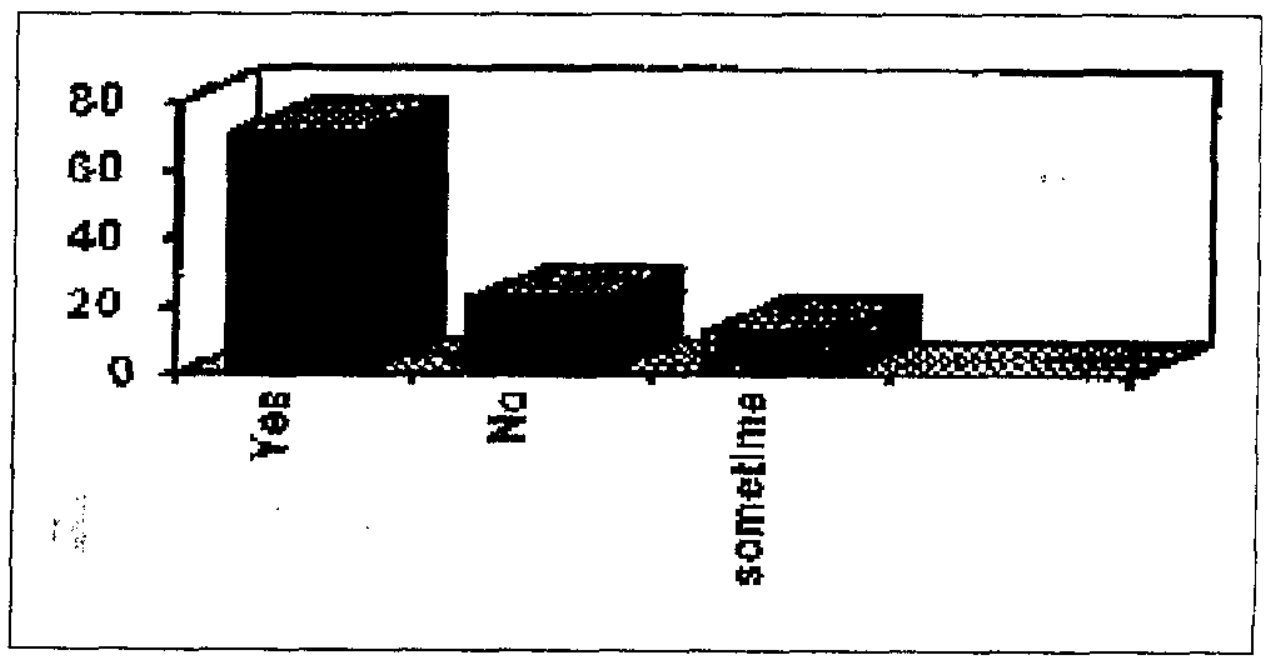

Fig (3) statistical analysis of using the safety equipments

This means that around $30 \%$ of the work force are unaware about their safety needs are in great physical danger, one reason why these employees disregard the safety equipment is because it causes some agitation when it is worn. $80 \%$ of the employees answered, "Yes" when asked, "Does the safety equipment cause any agitation? Fig (3)

The second section of the questionnaire relates to health, which is the most important factor in this investigation. It shows that $50 \%$ of the employees who answered the questionnaire have various skin and chest diseases, $20 \%$ of the employees complained of eye, throat and stomach upsets, $25 \%$ suffered allergies caused by smell and dust. It should be noted that most of those who 
answered the questionnaire have no knowledge about how their illness came about.

All the diseases can be seen in Fig (4). It shows that the skin, throat and chest are the most common complaint whilst the eye, throat and stomach upsets are the least common.

There was no indication that there is any life threading diseases from the answers given by the employees. Dust, bad smells, noise, lack of air condition and lack of light are represented in Fig. (5)

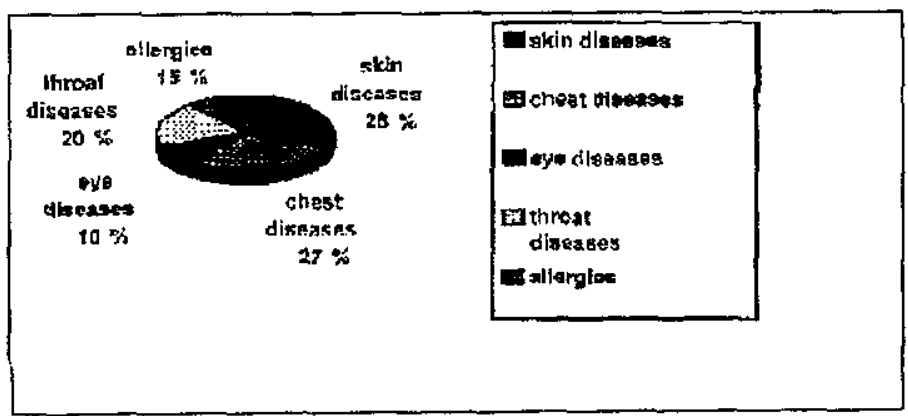

Fig (4) statistical analysis of employees' diseases

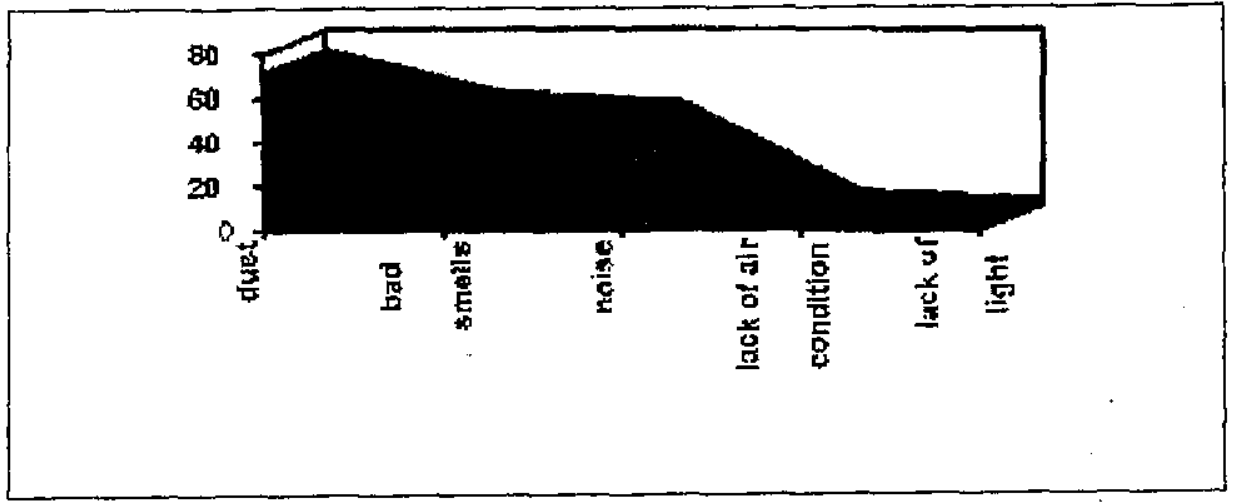

Fig (5) the environment conditions surroundings the employees

It shows that dust ettect on those employees most $(/ U \%)$ tollowed by bad smells and noise. The highest factor of complaint comes firstly from dust, bad smells and noise. Whilst the lack of air-condition and light seem to be satisfactory. The investigation also notes that $70 \%$ of the employees state that the medical examination plan is poor. $85 \%$ state a preference to day shift rather than night. The employees also complain about a lack of break period. For an eight- hour shift the only break period they have is one hour for lunch. Accommodation, transport, entertainment, communication and meals and there degree of available are shown in Fig. (6). 


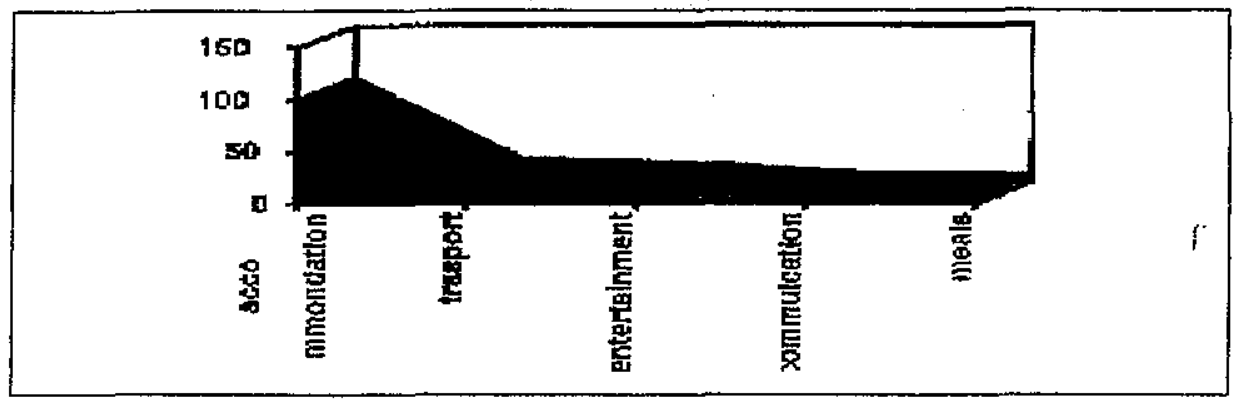

Fig (6) services and aids are submitted to the employees

\section{Conclusions}

1. Those hospitals and factories, which deal with chemical waste, should separate their waste to avoid any direct contact to those who collect and recycle making it a healthier, less dangerous aspect of recycling.

2. It is necessary to introduce a project which educates the public on house waste recycling, such a project could include a huge collection center where the deposit their own household waste into bins. The bins would hold different articles for recycling bottle bin, aluminum bin, paper bin etc.

3. A regulation or law should be introduced which protects the environment from our pollution, in Europe this problem has largely decreased because the cars have to pass tests to be able to go on the rgad. The investigation shows that most of the employees suffer from chestand skin ailments, the author therefore recommends that an annual medical examination is carried out to protect the employees.

4. It is necessary that the employees rotate so that they are not situated in the same condition permanently.

5. Education of the employees is necessary so that they are aware of the safety equipment.

6. The safety equipment should pass a world safety organization group test and should be tested regularly.

7. A bonus plan should be introduced, especially for those employees who work night shifts, which enables them to work both night and day shift in turn.

8. A break period of $15 \mathrm{~min}$ in the morning and $15 \mathrm{~min}$ in the mid- afternoon is necessary to enable the employees to regain concentration, especially for those who operate machinery, which would then no doubt decrease the accidents which occur.

9. The author recommends that the researches in this field continues and its necessary that professionals such as medical doctors and safety specialties contribute there knowledge to come up with a better solution to this problem. 


\section{References}

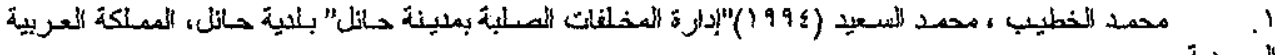

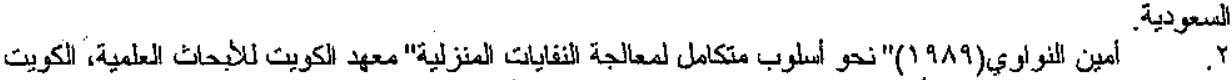

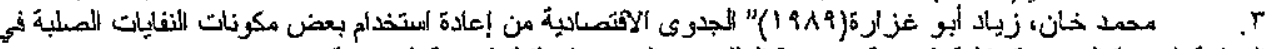

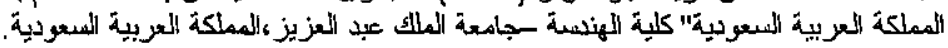

4. MacDonald, M. L. (1996) "Solid waste management models", Journal of Solid Waste Technology and Management, v23, n2, pp.73-83.

5. Graziano, D. J. and Daniels E. J. (1996) "New approaches to waste oil reduction and reuse"

6. Bryant G. and Tolson L. (1988) " Newark claims east coast's largest recycling program", World Wastes, v3 1, n12, pp.47-49

7. Morgan, W.K.C.and Reger, RB. (1997) "Health effects of diesel emissions" Annals of Occupational Hygiene v41, n. 6, pp 643-658.

8. Buurstyn, Igor, Teschke, Kay, Kennedy and Susan (1997) "Exposure levels and determinants of inhal able dust exposure in bakeries" JA 0003-4878.

9. Kelli, Davis and Shannon (1996) "Continues exposure to noisy work environments does affect preferred leisure noise levels" Int. Journal of Industrial Ergonomics" v 17, n 6, pp.499-511. 


\section{Appendix (I) \\ QUESTIONNAIRE}

Effects of Waste Recycling on The Employees and The Environment

- Please, try the following, your answers are very important to us.

1- Define the Age: Height: Status: Weight:

2- Tick 'Yes' or 'No' to the following movement which put strain on you:

-360 turn: O Yes O No - Hand lift above shoulder: O Yes .O No.

- Working pedals by feet: O Yes O No - Walking: O Yes O No.

-Waiting period: OYes ONo - Standing: OYes ONo.

3- Is there any safety equipments available?

Tick 'Yes' or 'No' to the following equipment;

- Glasses / Goggles: O Yes O No - Safety shoes: O Yes O No

- Gloves: OYes ONo

If any other safety equipments is used, please state:

- Do you wear the safety equipment available? O Yes O No O Sometimes

- Do the safety equipment agitate you while wearing it?

O Yes ONo O Sometimes

- If the answer is 'Yes', please write?

4- Working hours: $O$ morning shift $O$ afternoon shift $O$ night shift

- Which of the above shifts do you prefer and why?

- How many breaks and for what duration is each break during each shift?

5- On the production line, do you stay at the same position all the time or move around'?

$O$ yes ONo

6- Does your job provide you with any of the following? Tick 'Yes' or 'No' - accommodation: O Yes
O No
- communications: $\mathrm{O}$ Yes
- transport:
$\mathrm{O}$ Yes
O No..
O No.
- any meals provided: $\mathrm{O}$ Yes

- pleasure activities: $\mathrm{O}$ Yes

O No.

O No 
7- How good is the moral and financial encouragement?

$O$ excellent $O$ good $O$ bad $O$ poor

8- How would you describe the condition of your health before join the factory?
$O$ excellent
O good
$\mathrm{O}$ bad
O poor

9. How would you describe the condition of your health alter joining the factory?
$O$ excellent
$\mathrm{O}$ good
O bad
O poor

if any change has occurred to your health, please state what, when and where?

10- Please tick 'Yes' or 'No' to any of the following, did your work affect your

-Skin:

$\mathrm{O}$ Yes $\mathrm{O}$ No.

- Throat:

O Yes $\mathrm{O}$

- Chest:

$\mathrm{O}$ Yes $\mathrm{O}$ No.

No.

-Eye:

$\mathrm{O}$ Yes $\mathrm{O}$ No.

- Other, please state:

11 - If you have any knowledge about the cause, please state?

12- Have you had any sickness while employed by the factory?

How many?

How long?

Do you have an idea about the period you worked before this sickness occurred?

13- How long have you been working in this factory?

How long and how often is your holiday period?

14- How would you describe the health treatment and examinations provided by the factory?
$O$ excellent
O good
O bad
O poor

15- Do you face any of the following problems in the work place? Tick 'Yes' or 'No'

- Smell: O Yes ONo. - Dust: O Yes O No.

- Contaminated water: O Yes O No.

- Lack of air condition: O Yes O No

-Noise: O Yes O No. - Lack of light: O Yes O No.

- Other:

16- How sufficient is the accident emergency treatment:

$O$ excellent $\mathrm{O}$ good $\mathrm{O}$ bad $\mathrm{O}$ poor

17- How often do accidents occur in the factory?

O Regularly O Sometimes O Hardly ever O None 
18- How do these accidents occur?

Answer the following questions if you are an engineer:

19- How often does the production stop due to a fault in machinery?

O Regularly O Sometimes O Hardly ever O None

20- How fast does it take the maintenance team to respond and repair the fault?

O Quickly $O$ average $O$ very slow 
تدويز النفايات وتأثير ها على العاملين والبيئة

الكلية التقنية بحائل_المملكة العربية السعودية النعيسة

تمثل النفابات هشكلة حقيقية لها تهليد مباشر على الصحة و البيئة خاصة إذا ما كانت تحتوي يزلنم، مخلفات نووية.. وأستحوذ التخلص من التفايات وتدويرها الاهتمام الأكبر للباحثيز ذيلهل العقد الماضي، إلا أن الدراساث المتعقة بتأثير النفايات علي المتعاملين معها لم تستحوذ على الاهتمام الكافي بعد. تحتوي هذه الار أسة على نتائتج استبيان للعاملين بمصنع تدوير النفايات بمنطقة حائل بالمملكة العربية السعودية (طاقة إنتاجية ، . ب طن/يوم) ، شملت هذه الإزاسة على أوجه عدة مثل تأثير ها على الصحة و الأمر اض المختلفة التي تعرضوا لهاو تأنثير ها على البيئة ومدى توفز وسائل الفحص والأمن الصناعى . أظهرت الدر اسة تعرض العاملين لأمر اض مختلفة من التهابات جلدية إلي لي صدرية مما يستوجب الفحص الطبي الدوري مع ضرورة التغييز المستمر في من وظائف المعاملين بالمصنع · 